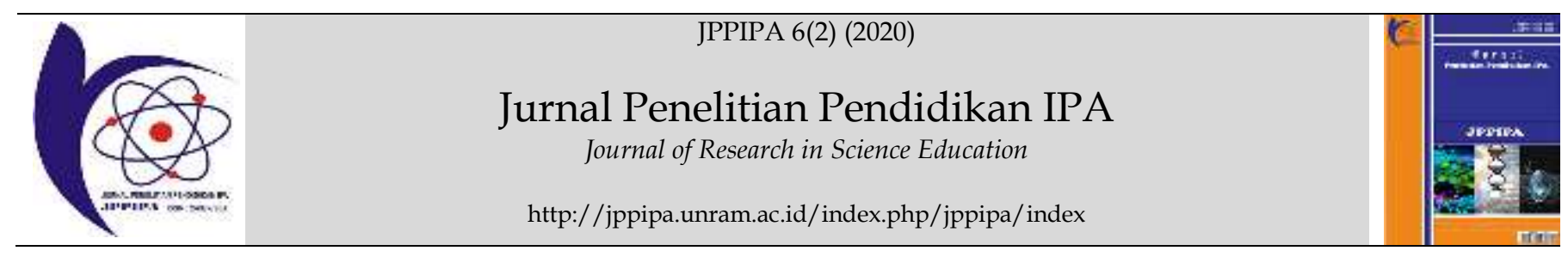

\title{
Mastery Concept of Harmonic Vibration with Meaningful Instructional Design Learning Model through Experimental Methods
}

\author{
Mila Armiati ${ }^{*}$, Ahmad Harjono ${ }^{1}$, Susilawati ${ }^{1}$ \\ ${ }^{1}$ Physics Education Program, FKIP, Universitas Mataram, Mataram, West Nusa Tenggara, Indonesia.
}

\section{DOI: $10.29303 /$ jppipa.v6i2.353}

\section{Article Info}

Received : December 28th 2019

Revised : June $26^{\text {th }}, 2020$

Accepted : July $1^{\text {th }}, 2020$

\begin{abstract}
This research was aim to identify the effect of meaningful instructional design (MID) learning model through experimental methods on mastering the concept of harmonic vibration. This type of research was quasi experiment with nonequivalent control group design with pre-test and post-test. The population was all students class X MIA SMAN 7 Mataram in the academic year 2018/2019 with a purposive sampling technique. Class X MIA 4 was chosen as the experimental class with MID learning model through the experimental method and class X MIA 5 as the control class with conventional learning. Concept mastery data were analyzed using the polled variance t-test. The results of the analysis were $t_{\text {count }}>t_{\text {table }}(4.39>2.00)$ at a significant level of $5 \%$ which means that $H_{a}$ was accepted and $\mathrm{H}_{0}$ was rejected. Concluded that there was the effect of the meaningful instructional design (MID) learning model through the experimental method of mastering the concept of harmonic vibration.
\end{abstract}

Keywords: Meaningful instructional design; experimental method; mastery concept.

Citation: Armiati, M., Harjono, A., \& Susilawati. (2020). Mastery Concept of Harmonic Vibration with Meaningful Instructional Design Learning Model through Experimental Methods. Jurnal Penelitian Pendidikan IPA (JPPIPA), 6(2), 199-204. doi: https:// doi.org/10.29303/jppipa.v6i2.353

\section{Introduction}

Physics is the study of natural phenomena and the interaction of natural phenomena itself (Kanginan, 2004). Physics is part of science and is a collection of knowledge, ways of thinking, and inquiry (Astusi, 2015). Sari et al (2016) stated that physics as a collection of knowledge can be in the form of facts, concepts, principles and physical laws. Meanwhile physics as a way of thinking or how to behave because the initial way of acquiring knowledge of physics requires mental processes and attitudes that originate and thoughts such as observing, investigating or conducting experiments and physics as an investigation shows physics as a process of gaining knowledge through a process called a method scientific (Sugiana et al: 2017). Physics is a science with a limited scope of study only on empirical matters, namely a source of knowledge obtained from observations or experiments (Sakti, 2015).

The scope of physics studies is limited to empirical matters, emphasizing learning experiences such as practical activities will support students to find concepts while developing students' critical attitudes (Hasbi, et al: 2015). Practicum activities in schools will also support the maximum use of learning media by teachers and students so that their existence can provide more benefits in learning. This is in accordance with the principle of the use of instructional media.

Based on the results of preliminary studies in the form of interviews and questionnaires given at Senior High School of 7 Mataram, the results obtained that the physics learning process in the classroom continues to be developed. The main development lies in the learning model that is applied. There are three learning models commonly used by teachers in teaching 
physics, namely direct instruction (DI), cooperative media assisted by virtual media and guided inquiry. The characteristics of class $X$ indicate active students, learning outcomes that are normally distributed and give positive responses when facilitated for learning in the form of virtual simulations, experimental tools or demonstrations. For class X, during the last semester, only one experiment was conducted on the material Irregular Straight Motion and Irregularly Straight Motion material. This is due to the limited availability of experimental tools. The mastery of class $X$ concepts is around $75 \%$ in the knowledge domain to the application domain and around $25 \%$ in the synthesis domain until analysis. The domain of creation is still very minimal, the test results show that only one child has succeeded in solving problems in the domain of creation. Based on giving questionnaires containing questions about physics lessons in class XI MIA 5 at SMAN 7 Mataram. Obtained results show that physics is a lesson that is less desirable by students.

Physics is still considered a difficult subject, boring, always serious, full of formulas, and application is very limited when associated with everyday life. Some students stated that learning physics should be supported by conducting experiments so that learning is more meaningful. They revealed that it was still difficult to answer questions, memorize formulas, choose equations that were appropriate to the context of the problems, and understand the concepts of physics. Students feel that physics has less to do with everyday life and is filled with equations and mathematical calculations only. Based on these problems, the teacher needs a learning model that can support the meaningful learning process, so the Meaningful Instructional Design (MID) Model is used. The MID model is a learning model that was built conceptually to realize meaningful and effective learning. This model puts forward a case example in daily life or something that is known to students, then linked to the subject matter so that students are expected to understand the subject matter (Sritresna, 2015). Research conducted by Dayu (2016) also shows that MID models in learning can support students' writing abilities for the better. In addition to the delivery of material by choosing the right path, the meaningfulness of the learning process also requires adequate facilities to prove abstract concepts of physics learning to make it more concrete.

The solution proposed by researchers is to combine MID models through the experimental method. Experimental methods in several studies have shown positive results. Handhika (2012) states that there is an influence of learning models with experimental methods on the mastery of students' concepts. A similar study conducted by Astuti et al
(2012) also states the same thing, that there is a high or low effect of learning outcomes of students who get experimental methods when learning takes place. In addition, the experimental method was chosen because of its application using instructional media. Several studies have shown that the addition of media to prove physical concepts shows positive results. This finding is supported by research conducted by Rosmiliasari et al (2014) and Marliana (2017) which show that there is a positive influence of media-assisted MID models on student learning outcomes.

Collaboration between MID learning models through the experimental method with additional harmonic vibration experiment tools is expected to complement each other. MID learning models that focus on strengthening apperception and learning experiences will be further strengthened by the support of experimental activities using learning media in the form of practical tools. The MID learning model will make learning meaningful and the experimental method using practical tools will provide direct experience to students in gaining knowledge. Meaningfulness and experience of the learning process will encourage increased mastery of students' physics concepts.

\section{Method}

This type of research is a quasi-experiment to look for the influence of certain variables with other variables under controlled conditions. This research involves independent variables, namely MID learning models through experimental methods and the dependent variable, namely the mastery of students' concepts. The study population was all students of class X MIA SMAN 7 Mataram. The study design uses a non-equivalent group design or also known as an untreated control group design with pretest and posttest shown in Table 1 below.

Tabel: Research Design

\begin{tabular}{llll}
\hline class & Pretest & Treatment & Posttest \\
\hline Experiment & $\mathrm{O}_{1}$ & $\mathrm{X}$ & $\mathrm{O}_{2}$ \\
control & $\mathrm{O}_{1}$ & - & $\mathrm{O}_{2}$ \\
\hline & & (Setyosari, 2013)
\end{tabular}

Note:

$\mathrm{O}_{1} \quad$ : Pretest

$X$ : Provision of treatment in the form of MID learning models assisted with Practicum Tools

$\mathrm{O}_{2} \quad$ : Posttest

- $\quad$ : The treatment is in the form of conventional learning

The sampling technique used was purposive sampling, with certain reasons including, students taught by the same teacher, hours of physics lessons 
that are not much different, the average value of daily tests in the same category, the number of students is relatively the same, and there is a teacher's recommendation to take the class.

Class X MIA 4 as an experimental class and class $X$ MIA 5 as a control class. The test instrument is in the form of 20 multiple choice questions to measure the mastery of concepts in the knowledge domain until it is creative. The data analysis test uses polled variance $\mathrm{t}$ test, with degrees of freedom $(\mathrm{dk})=\mathrm{n}_{1}+\mathrm{n}_{2}-2$ and $\mathrm{a}=$ 0.05 .

\section{Result and Discussion}

The study began by providing an initial test of mastery of concepts in both classes. After giving the initial test, the researchers gave different treatments in the two classes. To measure the effect of the treatment that has been given, both classes are given a final test with the same material, number, and weight of questions as the initial test.

The results of the study illustrate that concept mastery is still low both in the experimental class and the control class. This can be seen from the average value of the initial test of mastery of the concepts of each class. The average value is still low because the two classes have not obtained the harmonic vibration material according to their level. Students' knowledge is only limited to the basic knowledge they have obtained from junior high school, other references, and their experiences in the surrounding environment. After being given treatment, there is an increase in the average value in both classes which is more significant. Final test results show, the experimental class obtained an average value of 77.42 higher than the control class with an average value of 68.03 . Increasing the average mastery of the concept of harmonic vibrations of students in the control class and experimental class is presented in Figure 1.

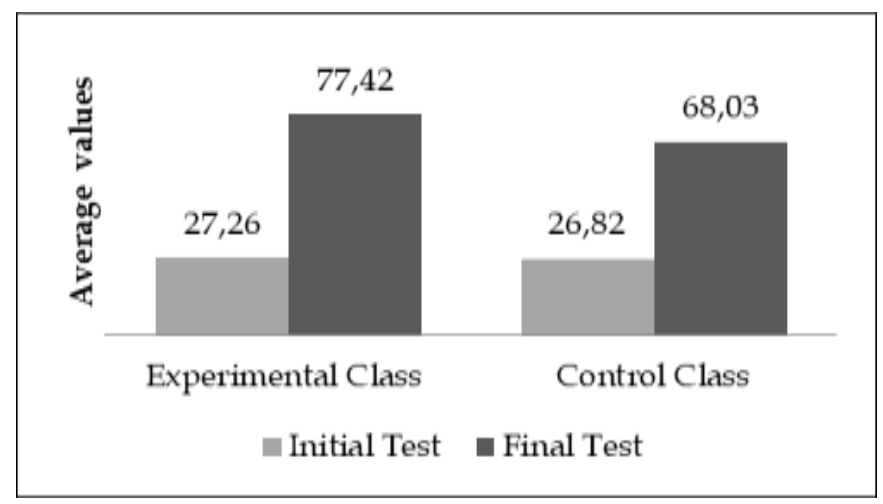

Figure 1. Average ability of initial test and final test mastery of concepts.
Based on Figure 1, the two classes have increased, but there are differences in the increase in values between the experimental class and the control class. The experimental class showed higher results. The difference is due to the effect of different treatments between the two classes, so it can be stated that the MID learning model through the experimental method affects the mastery of the concept of harmonic vibrations of students. This is in line with the opinion of Smaldino, et al. (2012) which states that learning involving the process of engineering or manipulation of real objects can provide concrete experiences so as to clarify the concepts being learned.

Statistical analysis was performed to further substantiate the normality test and homogeneity test data for the initial and final tests. Based on the test results found that the data are normally distributed and homogeneous. The next analysis is to test the hypothesis using an independent $t$ test with the polled variance formula and the value of $t_{\text {count }}$ is 4.39 greater than the $t_{\text {table }}$ with a value of 2.00 . So, it can be concluded that there are significant differences in mastery of concepts due to the influence of the application of MID learning models through the experimental method. MID models through the experimental method can improve students' mastery of physics concepts because students are trained to research given problems, thus encouraging students to be active in finding answers to their problems. Each stage in the MID model has its own influence. However, according to the researchers' predictions, the reconstruction phase is the main stage in this model. Reconstruction becomes an important part because at this stage students reshape their knowledge if there is still a gap between the initial knowledge with the teacher's explanation. This stage is also a place in conducting experimental activities to provide learning experiences in gaining knowledge independently.

The researcher predicts that the successful application of the MID learning model through the experimental method is due to students getting facilities to connect new phenomena into their knowledge structures. This is in line with the opinion of Utami et al (2014) which states that students who can connect new phenomena into their knowledge structures make student learning outcomes more optimal. The support provided for the experimental class is in the form of providing practical tools to explain more concrete material and these tools are not only used when practicing, but also concurrently as a teaching aid to explain concepts that can be demonstrated. This activity provides direct experience for students in realizing abstract concepts commonly found in theory to be more concrete. 
The findings in this study were reinforced by Sritresna (2015) and Utami et al (2014) that the MID learning model is better than the conventional model. This is seen from students who respond to the lesson and get the impression and understanding of the material better so that it supports the ease of receiving teaching material from the teacher. This model also makes students' communication better when conveying the results of the discussion in front of the class. These results are in line with the results of Muningsar's research (2016) which states that an increase in the communication effectiveness of students after getting MID learning. This is predicted because students get more meaningful learning based on the stages of the MID learning model. This is also supported by the existence of practicum activities as well as demonstration of concepts that can be concretized by the existence of experimental methods in each meeting.

The experimental method provides direct experience for students in finding learning concepts so that learning becomes a fun and more real activity. This is consistent with the results of research conducted by Sakti (2011) which states that practicum activities have a positive impact on the cognitive and psychomotor abilities of students. Several other studies that also support this result are Rosmilasari et al (2014), Jamuri et al (2015) which states that there is an influence of MID models assisted by learning media on learning outcomes and there are significant results on increasing student achievement motivation. Marliana (2017), Jannah et al, (2016) also found a similar thing, namely there was an increase in the cognitive abilities of students who applied interactive multimedia-assisted MID models in learning.

Experimental methods applied in learning by using practical tools help students make learning more real. Collaboration between MID models and learning media will have a positive impact on learning. This is reinforced by previous research on MID learning models with the formation of instructional media, according to Rosmilasari et al (2014), Pramudyawan, et.al (2020) which states that there is an influence of MID models assisted with learning media on learning outcomes and there are significant results on increasing student achievement motivation. A similar result was also found by Marliana (2017) in that there was an increase in the cognitive abilities of students who applied interactive multimedia-assisted MID models in learning.

Increased mastery of students' concepts in the cognitive aspects of knowledge to create is illustrated in Figure 2 as follows.

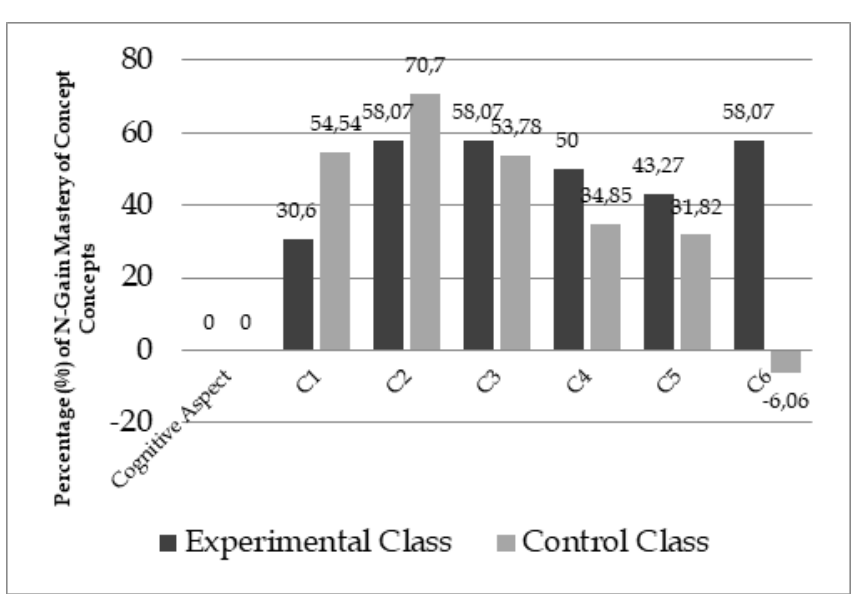

Figure 2. Improved cognitive aspects of students.

Based on Figure 2 it can be seen that overall the students' mastery of concepts in the experimental class has increased higher than the control class either per indicator of mastery of concepts in harmonic vibration material. The increase is due to the experimental class students build their own knowledge through research exercises to solve the problems given by the teacher so that they have a better mastery of concepts than the control class. Application of the experimental method with the principle of the use of media in learning also further strengthens the picture of students about the phenomenon under study.

Slightly different results are shown in the domain of creating cognition which shows no increase in the control class. In addition, this is thought to be due to the continuation of the treatment given to the control class that does not facilitate the resolution of problems at a high level of cognition. Different results are shown by the increase in domain creation which shows high interprets. One fundamental difference in the experimental and control classes lies in the use of instructional media and the meaningful learning models that are applied. Questions in this domain require structured understanding and demand understanding of cause and effect. In the experimental class, students are given a more real picture by demonstrating it using the stratified pendulum and then varying its position to analyze the factors related to the amount of energy in each pendulum position. While in the control class, this concept is only depicted in two dimensions on a blackboard which is predicted to make students less understanding and remembering the concept even though it has been explained. Increased mastery of students' physics concepts is also in line with the results of the N-gain test per learning indicator. $\mathrm{N}$-gain test results in the experimental class as a whole showed an increase. The results of the Ngain test per learning indicator are presented in Table 2. 
Table 2. N-Gain scores per- Competency Achievement index (CAI)

\begin{tabular}{lllll}
\hline \multirow{2}{*}{ CAI } & \multicolumn{2}{l}{ Experimental Class } & \multicolumn{2}{l}{ Control Class } \\
\cline { 2 - 5 } & $\begin{array}{l}\text { N-Gain } \\
\text { scores }\end{array}$ & Note & $\begin{array}{l}\text { N-Gain } \\
\text { scores }\end{array}$ & Note \\
\hline CAI1 & 1 & High & 0,95 & High \\
CAI2 & 1 & High & 1 & High \\
CAI3 & 0.83 & High & 0.52 & Medium \\
CAI4 & 0.78 & High & 0.81 & High \\
CAI5 & 0.66 & Medium & 0.46 & Medium \\
CAI6 & 0.51 & Medium & 0.03 & Low \\
\hline
\end{tabular}

Based on Table 2 it can be seen that each CAI has increased both in the experimental class and the control class. The highest increase in the class given MID model treatment through experimental methods with 4 CAI increased in the high category and two CAI in the medium category. This result is caused by the provision of enrichment to students combined with experimental activities to produce meaningful learning. The control class also showed consistent results, but did not experience a more significant increase than the control class. The category of improvement of CAI 6 test results in the control class is in the low category. This is because the questions in the realm of CAI 6 are included in the high category, namely in the cognitive domain C5 and C6.

Some of the obstacles experienced by researchers during conducting research are the ability to organize groups when conducting practical work and time efficiency when conducting practical activities. This makes researchers lack of learning time and there are limitations in peeling thoroughly the enrichment given to both classes. Especially in the experimental class who also do practical activities that require extra time.

Based on the theory and findings in this study it can be stated that the MID learning model through the experimental method can help students to get more meaningful information by connecting previous knowledge with new knowledge. In line with this, the MID model, if implemented properly, can support better communication effectiveness.

Experimental method assistance is very useful in the transfer of knowledge in accordance with Ausubel's opinion which states that meaningful learning is greatly supported by the provision of adequate learning tools. The MID model is designed so that students can learn more contextually and concretely so that the production of learning outcomes can not only be in the form of improved test results but also learning experiences. This will make learning more meaningful.

\section{Conclusion}

Based on the results of the study, it can be concluded that the MID learning model through the experimental method affects the mastery of students' physics concepts. MID learning models can be an alternative to physics learning by teachers. This learning model will be even better if implemented with the help of instructional media. However, its application requires careful planning and preparation so that learning can proceed according to the objectives to be achieved. The time spent during the course of learning must be used efficiently by planning a balanced allocation of time for each learning phase. The division of groups when applying this model should use groups with members that are not too large so that the purpose of the MID model as one of the cooperative learning models can be in the form of more intensive interaction and collaboration among group members. The amount of learning media provided should not be too small, so that each student has experience in operating the media. The teacher should be able to arouse the desires of students in giving apperception by explaining the facts or problems presented. For further research on MID learning models can be done on different material with a broader research subject

\section{Anknowlagemnet}

Thank you to the Principal of Senior High School of 7 Mataram for allowing him to research at the school and to the teachers who have helped researchers in completing their research. The same remarks for the research study of Physics Education program FKIP Post-Earthquake Universitas Mataram which have provided support in the form of funding are used to provide learning media in this research

\section{References}

Astuti, R., Sunarno, W., \& Sudarisman, S. (2016). Pembelajaran IPA dengan pendekatan ketrampilan proses sains menggunakan metode eksperimen bebas termodifikasi dan eksperimen terbimbing ditinjau dari sikap ilmiah dan motivasi belajar siswa. In Proceeding Biology Education Conference: Biology, Science, Enviromental, and Learning. 13(1). 338-345.

Astuti, S. P. (2015). Pengaruh kemampuan awal dan minat belajar terhadap prestasi belajar fisika. Formatif: Jurnal Ilmiah Pendidikan MIPA, 5(1). http://dx.doi.org/10.30998/formatif.v5i1.167.

Dayu, D. P. K. (2016). Keefektifan Penggunaan Model Mid (Meaningful Instruksional Design) 
Terhadap Keterampilan Menulis Cerita Pada Pembelajaran Bahasa Indonesia Siswa Kelas 5 Sekolah Dasar. Premiere Educandum: Jurnal Pendidikan Dasar dan Pembelajaran, 6(02). http://doi.org/10.25273/pe.v6i02.812.

Handhika, J. (2010). Pembelajaran Fisika Melalui Inkuiri Terbimbing Dengan Metode Eksperimen Dan Demonstrasi Ditinjau Dari Aktivitas Dan Perhatian Mahasiswa1. Jurnal Penelitian Pembelajaran Fisika, 1(1). 10.26877/jp2f.v1i1.104.

Hasbi, M. A., Kosim, K., \& Gunawan, G. (2015). Pengembangan Alat Peraga Listrik Dinamis (APLD) Berbasis Inkuiri Untuk Meningkatkan Penguasaan Konsep Siswa. Jurnal Penelitian Pendidikan IPA, 1(1). 10.29303/jppipa.v1i1.6.

Jamuri., Kosim., \& Doyan, A. (2015). Pengaruh Model Pembelajaran Kooperatif Stad Berbasis Multi Media Interaktif Terhadap Penguasaan Konsep Siswa Pada Materi Termodinamika, Jurnal Penelitian Pendidikan IPA, 1(1), 123-134, doi : 10.29303/jppipa.v1i1.11

Jannah, S.N., Doyan, A., \& Harjono, A. (2016). Pengaruh Model Pembelajaran Kooperatif Dengan Pendekatan Problem Posing Ditinjau Dari Pengetahuan Awal Terhadap Penguasaan Konsep Fisika Siswa SMK, Jurnal Penelitian Pendidikan IPA, 2(1), 17-27, doi:10.29303/jppipa.v2i1.29

Kanginan, M. (2004). Fisika Untuk SMA Kelas X. Jakarta: Erlangga.

Marliana, S. (2017). Penerapan Model Pembelajaran MID Berbantuan Multimedia Interaktif Berbasis Animasi Untuk Meningkatkan Kemampuan Kognitif Siswa SMK. Doctoral dissertation, Universitas Pendidikan Indonesia).

Muninggar, L.A. (2016). Keefektifan Implementasi Model Pembelajaran Mid Terhadap Kemampuan Komunikasi Matematis Peserta Didik Kelas Vii SMP Negeri 1 Wanadadi. Doctoral dissertation, Universitas Negeri Semarang).

Pramudyawan, M.T.S., Doyan, A., \& Ardhuha, J. (2020). Pengaruh Model Pembelajaran Inkuiri Terbimbing Berbantuan Kit Alat Percobaan Usaha dan Energi terhadap Penguasaan Konsep Fisika Peserta didik, Jurnal Penelitian Pendidikan IPA, 6(1), 40-44, doi: 10.29303/jppipa.v6i1.290

Rosmilasari, D. M. A. R., Sujana, I. W., \& Wiarta, I. W. (2014). Pengaruh Penerapan Model Pembelajaran Meaningfull Instructional Design (MID) Berbantuan Media Teka-Teki Silang Dan Motivasi Berprestasi Terhadap Hasil Belajar IPS Siswa Kelas V SD Gugus Untung Surapati Denpasar Timur. MIMBAR PGSD Undiksha, 2(1). http://dx.doi.org/10.23887/ijpgsd.v2i1.2475.
Sakti, I. (2011). Korelasi Pengetahuan Alat Praktikum Fisika dengan Kemampuan Psikomotorik Siswa di SMA Negeri Kota Bengkulu. EXACTA, 9(1), 67-76.

Sari, P. I., Gunawan, G., \& Harjono, A. (2017). Penggunaan Discovery Learning Berbantuan Laboratorium Virtual pada Penguasaan Konsep Fisika Siswa. Jurnal Pendidikan Fisika dan Teknologi, 2(4), 176-182. http://dx.doi.org/10.29303/jpft.v2i4.310.

Setyosari, P. (2010). Metode Penelitian Pendidikan dan Pengembangan. Jakarta: Prenada Media Group.

Smaldino, E.E., Lowther, D.L., \& Russel, J.D. 2011. Teknologi Pembelajaran dan Media untuk Belajar. Arif Rahman (penerjemah). 2012. Jakarta: Kencana.

Sritresna, T. (2015). Meningkatkan kemampuan koneksi matematis siswa melalui model pembelajaran Cooperative-Meaningful Instructional Design (CMID). Mosharafa: Jurnal Pendidikan Matematika, $4(1), 38-47$.

Sugiana, I. N., Harjono, A., Sahidu, H., \& Gunawan, G. (2017). Pengaruh Model Pembelajaran Generatif Berbantuan Media Laboratorium Virtual Terhadap Penguasaan Konsep Fisika Siswa pada Materi Momentum dan Impuls. Jurnal Pendidikan Fisika dan Teknologi, 2(2), 61-65. http://dx.doi.org/10.29303/jpft.v2i2.290.

Utami, N. K. R., Suadnyana, I. N., \& Meter, I. G. (2014). Pengaruh Model Meaningfull Instructional Design Bermuatan Masalah Kontekstual Terhadap Hasil Belajar IPA di SD Negeri 1 Renon. MIMBAR PGSD Undiksha, 2(1). http://dx.doi.org/10.23887/jipgsd.v2i1.1955. 